\title{
Fostering Non-English Major Undergraduate Students' Writing Skill: A Study in Cumilla Region of Bangladesh
}

\author{
Renaissance Ahmed Sayma \\ Lecturer, Department of English, Comilla University, Cumilla, Bangladesh
}

\begin{abstract}
In Bangladesh, English is taught as a compulsory course from class one till class 12. Still, the undergraduate students of Bangladesh cannot convey their thoughts in English. Students who come from the Bangla medium and pursue study at Tertiary level in non-English major subjects, they face enormous difficulties in their academic writing class. The present study aims to explore the writing problems of non-English major undergraduate students at Tertiary Level in Bangladesh. The study was conducted on 120 non-English major undergraduate students from different departments studying at Comilla University, Britannia University and National University. The study also has 30 teachers as participants. In this paper, the mixed approach method has been used, and data have been collected through questionnaires. Based on the data analysis, it's perceived that Bangladeshi universities do not have well-integrated syllabus on academic writing to provide the chance of fair practice of writing skill in the classroom. This study also explores the importance of error analysis and error feedback, through which the teacher can motivate students to improve their writing. Besides, a few recommendations are provided to overcome writing problems.
\end{abstract}

Keywords: Non-English major undergraduate students, writing problems, grammatical, spelling errors, feedback, English course, Tertiary level.

DOI: $10.7176 / J L L L / 69-06$

Publication date:June 30th 2020

\section{Introduction}

Writing is a strategy for speaking to language in a visual structure. It plays a significant role in expressing one's ideas, thoughts, opinions, and attitudes. In communicative pedagogy, writing is one in all the four necessary language skills. It holds a significant part of learning a language because students are to sit for an examination to prove their competence by writing correctly. Even the English language has been implemented as a medium of teaching in universities as English has grown to be "the medium of a great deal of the world's knowledge" (Crystal, 2003).

Hedge (1988:5) states that an excellent compact of writing in the English language classroom is undertaken as an aid to learning, such as to consolidate the knowledge of new structures or vocabulary or to facilitate students learn by heart new items of language. In this perspective, writing permits students to see their improvement, get feedback from the teacher, and empower teachers to monitor students and detect problems encountered. Thus writing plays a predominant role in language learning.

The dishearten news that most of the students are delicate in writing skills. Even after completing their secondary and higher secondary level, they are unsuccessful to prove their expected competency. However, compared to communication, effective writing calls for various things: a high degree of organization in the expansion of ideas and information; a high degree of accuracy so that there is no uncertainty meaning; the use of intricate grammatical patterns and sentence structures to generate a style which is appropriate to the subject matter and the ultimate readers (Hedge, 1988).

\subsection{Problem Statement}

In Bangladesh, universities offer different English language courses and core courses in various departments to teach writing as a skill. The purpose of these courses is to sharper learners' language skills for academic, professional, and individual goals. Nevertheless, the outcome is insufficient. The proficiency stage of English among students is shallow due to their educational background. Most of the students come from the Bengali medium, and they are not able to write effectively. That is why it is more challenging writing skills in the English language, especially whose English language course is non-major. The fact is that non - major English students always busy and keep thinking of their core courses. They want to get average marks in the English course. It shows their indifference in English that impedance their academic development. They are not motivated and feel bored and loaded in the English language classroom. They also feel frightened by the classroom tasks. That is why writing skills to non-English major students are problematic.

This study endeavors to identify the problems university students face when they write in English and suggest ways to overcome them. 
1.2 Aim

$>\quad$ To identify non- English major undergraduate students' writing problems.

$>\quad$ To investigate the reasons for feeling demotivated and bored in the English classes by the non- English major undergraduate students.

$>\quad$ To investigate the writing strategies employed by non-English major undergraduate students' prewriting, writing, and revising when writing in English.

$>\quad$ To investigate the teachers' attitude and the students towards error analysis and feedback in the writing classroom

1.3 Research Questions

1) What are the writing problems that non-English major undergraduate students face while writing in English?

2) Why do the non-English major undergraduate students feel demotivated and boring in English class?

3) What are the attitudes of the teachers and the students regarding error analysis?

4) What should be the strategies for error feedback?

5) What are the possible suggestions to improve writing problems?

1.4 Limitation

$>\quad$ Difficulty in collecting proper data.

Time is not sufficient to collect data in a broad range.

Face-to-face interviews consume time, so this study avoids students' interviews.

$>\quad$ The researcher faced difficulty in preserving data in Google drive.

1.5 Significance

This study is conducted to explore the writing problems and strategies used by non-English major undergraduate students. The study's main aim is to focus on the writing problems of the non-English major undergraduate students of Bangladesh, their behavior and attitudes and the problems they face while writing English in the classroom. This study also brings into light that the teachers have to move on from the traditional teaching method to the communicative teaching method to guide students to engage in a realistic context. This study will also be used as a guideline for both the teachers and students to know which strategies are useful to apply to improve students' writing problems at Tertiary level. The researcher also tries to discover the importance of error analysis to ensure students' errors and mistakes and help them correct their mistakes or errors under teacher's surveillance. As problems in grammar or organization of ideas in Tertiary level's writing is not tolerable, this study will suggest some possible recommendation for improving non-English major undergraduate students' academic writing. This study will help the syllabus designer to design the syllabus according to the need of the students.

\section{Literature Review}

2.1 Writing problems experienced by ESL/EFL students

Writing is the most demanding part in learning the second language. It is based on the proper and strategic use of language with structural accuracy and communicative potential (Dar\& Khan, 2015; Hyland, 2003; Mahboob, 2014). Kellogg (2001) opines that writing is a cognitive process that tests memory, thinking capacity and verbal authority to fruitfully communicate the ideas; because proficient composition of a text signifies successful learning of a second language (Geiser \& Studley, 2002; Hyland, 2003; McCutchen, 1984; Nicker-son, Perkins, \& Smith, 2014). As a result, learning how to write has increased great importance for the last two decades due to two factors: its use as a means for effective communication of ideas, and the all-embracing research work carried out in this area to inspect various issues faced by L2 writers (Dar \& Khan, 2015; Graham \& Perin, 2007; Haider, 2012; Hyland, 2003).

Students face various writing problems at different stages of their learning. Generally, these problems can be classified into linguistic, psychological, cognitive, and pedagogical categories (Haider, 2012; Hyland, 2003). They struggle with the structural components of English; because an unsuitable structure complicates the content and conception of the text, which a reader interprets through the association of a mental process (Quintero, 2008; Nik, Hamzah, \& Rafidee, 2010). Equally, an incoherent text fails to communicate ideas which cause a lack of confidence in learners though they have mastered syntactic, lexical, and grammatical control over text composition (Rico, 2014).

Students' lack of confidence is also caused by a teaching strategy that does not conform to students' learning approaches and cultural backgrounds (Ahmad et al., 2013). It is argued that poor writing skills derive from two factors: the teacher and the learner. Teachers require appropriate pedagogic approach to teach writing, including providing punctual and effective feedback to students, and most remarkably, teachers' lack of aptitude to motivate students. 
Alternatively, students face numerous challenges: the effects of L1 transfer lack of reading, motivation, and practice. In Pakistan, student writers meet psychological, cognitive, social and linguistic problems while converting ideas into text (Bilal, Tariq, Din, Latif, \& Anjum, 2013;Dar \& Khan,2015;Haider,2012;Mahboob \& Talaat,2008)

Complexities in writing can be shocking to a student's education. Heaton (1975) stated that requiring mastery are not only of grammatical and rhetorical devices but also of conceptual and judgmental elements. As students step forward, they are progressively more likely to express what they know about many different subjects through writing. If a student fails to develop specific necessary skills, he will be incapable to write with the swiftness and fluency required to surpass as these demands increase. Certainly, for a student struggling with a writing problem, the writing process itself hinders with learning. Students faced with such intricate odds have dilemma staying motivated.

According to Jordan (1977), writing is often confusing with putting words down on paper in the same structure as an outline prepared with appropriate style and vocabulary. The major ideas arranged in some often include the correction of mechanical and grammatical errors.

Bryne (1988) divided the problems that make writing difficult into three categories namely, Linguistic difficulty (grammar, vocabulary, language use and the choice of a sentence), Physiology difficulty (difficulty in developing written material or content of composition), and cognitive difficulty (spelling, punctuation, capitalization, and paragraphing).

For teachers, writing is measured a complicated skill to teach because it includes numerous components: a) comprehensive command of grammar, b) a grasp of spelling and punctuation, c) the use of appropriate vocabulary, d) a suitable style which meets the expectations of the readers, and e) organization skills (Musa, 2010). It also times consuming for teachers to read papers, to provide feedback, and to ask for correction. So, English writing tends to be neglected in the English language classroom (White \& Arndt, 1991).

In academic language, students are expected to produce coherent and well-organized written composition, as well as using the most apt vocabularies, sentence structure; and, most of all, productively communicate their ideas. Yet, the majority of ESL/EFL students experience difficulty in gathering these requirements; for instance, their essays are badly written in terms of the content, conventions, ideas, organization, sentence structure, and vocabulary. These students also have problems with establishing and achieving their communicative goals. In fact, producing a piece of writing, irrespective of whether or not it is a paragraph or an essay, seems to be chiefly problematic for ESL/EFL students because of the different rhetorical patterns used in English composition, including aspects such as organization, structure, and style (Leki, 1991).

Zamel (1982) identifies that students will enlarge the ability to write proficiently in English if they noticeably recognize and experience the procedure of composition. Some scholars and experts on writing (e.g., Brown \& Hood, 1989; Scholes \& Comley, 1989; Raimes, 2005) state that the writing process has three main stages: prewriting, drafting and revising. Surrounded by these three stages, writers usually practice many writing strategies, including brainstorming in the pre-reading stage; starting writing in the drafting stage; and adding, rearranging, and checking grammar, spelling, and punctuation in the revising stage.

Ahmed (1999) found in his study that Bangladeshi students are severely prone to making mistakes in English articles. He pointed out that mistakes occurred due to the differences between Bangla and English language. Mustaque. S. (2014) reveals that undergraduate students' writing samples display many errors, i.e., lexio-semantic errors, errors with verbs, prepositions, articles. She illustrates that the participants write without any planning, purposeless. Another study by Fahmida, B. (2010) identifies Bangladeshi tertiary level students' common errors in their academic essays. Different types of errors are spelling, punctuation, and organizational problems. She recommends that more concentrated English courses should be there before they take their major course in their respective area.

\subsection{Learners' Writing Problems}

Byrne (1988:4) thinks that because of the absence of the prosodic features in writing, the writer has to compensate these features by keeping the channel of communication open through his/her efforts by selecting appropriate structures and by using appropriate connecting devices so that the text can be interpreted on its own. Similarly, Hedge (1988: 5) thinks that so as the writer to compensate for the absence of the prosodic features in writing, he/ she has to write with a high degree of organization, watchful choice of vocabulary, and using complex grammatical devices. Grammatical problems, technical problems, sentence structure problems, and problems of diction are linguistic problems that obstruct students' effective writing in English.

\subsection{Grammatical Problems}

Learners have many problems in their attempts to write in the Second language. "As verbs take different forms depending on tense and subjects, they are used with, and they create problems for second language writing students" (Tyner, 1987). 


\subsection{Problem of Word Choice}

Good writing or composition should consist of an appropriate and varied range of vocabulary used along with proper grammar and varied range of sentence structures (Norish, 1983)White (1980) states that usually, students use 'big words' in their essays to impress the reader, their teacher. The effort to impress the reader leads to a problem of diction.

\subsection{Cognitive problems}

The cognitive problems that students face include problems of punctuation, capitalization, spelling, content, and organization.

a. Punctuation Problems

According to Byrne (1988: 16), the fact that punctuation has never been standard to the extent as spelling makes it is problematic.

\section{b. $\quad$ Capitalization Problems}

Capital letters are useful for sentence initials, the beginning of essential words, in topics, headings, etc. (Kroll, 1991). However, learners have problems in using capitalization properly. There are reasons for students' problems in using proper capitalization.

c. Spelling Problem

d. Content Problem

According to Leki (1991), this could be because of the traditional methods teachers use to teach writing for spelling, punctuation, and mastering grammar.

e. Problem Organization

Pincas (1982) has shown that learners have the problems of writing united paragraphs because of their failure to use cohesive devices appropriately.

\subsection{Causes of Learners' Writing problems}

2.6.1 Lack of Learners' Motivation

According to Leki (1991, p. 9), the desire on the part of the writer to communicate something is significant because it is much more difficult for students to write about something they have no interest in. Silva (1997) in Thomsan (2003) believes that it is both 'reasonable and motivating' to allow students to choose their topics and that when students are allowed this freedom, their work is more successful.

In addition, Pincas (1982: 4) thinks that motivation for all ages and levels increases if writing is placed in a realistic context. Byrne (1988:2) believes that most of the writers write less well if they are obliged to write about something that they do not want to write.

2.6.2 Inadequate Time

Learners need time for gathering ideas, organizing their ideas, writing drafts, proofreading, and re-writing. Thus the amount of time allotted to produce wiring might affect the mastery of the items mentioned above. In line with this, White and Arndt (1991) in Italo (1999: 47) state that "time is needed to incubate, sift and shape ideas. Of all the skills, writing is one which most benefits from time." The quality of students' written work can be affected by the amount of time that they are allowed in the process of teaching writing. Similarly Raimes (1983: 25) thinks that time is a crucial element in the writing process and distinguishes writing from speaking. Time may also be a key feature in producing a text full of control over organization and coherence. Also, many students and teachers feel that writing under time pressure is a very strange situation. They perhaps cannot lead them to produce compositions that are truly representative of their capabilities (Kroll, 1990: 140).

2.6.3 Lack of Practice

According to Davies (1998:25), "writing is basically a creative method, and good writers must become skilled at to communicate their ideas clearly to an unseen audience. This takes much practice.Grabe and Kaplan (1996:6) believes that writing does not come naturally but rather gained through continuous effort and much practice. Besides, learners must take responsibility for their learning if meaningful learning is to take place. He also adds that the best way to learn any skill would be to practice it. To become a good driver, the best way is to drive. Similarly, to become a proficient writer, the best way is again to writing a lot. Furthermore, Hedge (1988:11) states that "my own experience tells me that to become a good writer; a student needs to write a lot."

\subsection{Teachers' Feedback}

Zamel (1985: 79) states that teacher's feedback can be useful if teachers respond to students writing as genuine and interested readers rather than as judges and evaluators. Similarly, Byrne

(1988:29) thinks that if we are to be true readers rather than judges, we should perhaps look not at what the learners have failed to achieve but rather at what they succeeded in doing. This might help students, writers, to appreciate receiving comments and use them in their revisions.

Ferris (1995:49) thinks that teachers should not abandon constructive criticisms but should place it side by 
side with comments of encouragement. On correction errors, Norish (1983:71) writes:

"When considering the correction of errors as the stage of free writing, it is a helpful and inspiring exercise for the students to check their work in groups or pairs. This saves the teachers' time and encourages communication among the students."

However, in general, and in most cases, the teachers' feedback is unclear, inaccurate, and unbalanced. As a result, the feedback given does not help students develop their writing skills (Cohen and Cavalcanatic, 1990: 155). Zamel (1985) also found out that the written responses given by teachers were vague and abstract, which do not help students revise their writing. In addition to this, the corrections EFL teachers made were related to surface level problems, that is, focusing on spelling, tense, and punctuation forgetting content and organization of the writing that affect meaning and communication (Zamel, 1985; Cited in Alamirew, 2005: 100).

\section{Methodology}

3.1 Design of the study

This study is a mixed approach, a combination of qualitative and quantitative approaches in nature, in the field of teaching English language at the tertiary level's non-English major undergraduate students from private and public universities in Bangladesh. One hundred and twenty undergraduate students as well as thirty teachers took part in this research. This study has been conducted through the questionnaire survey within the students and teachers. Therefore, the questionnaires are prepared for both the Teachers and students, in where, the questions are mostly close ended..

\subsection{Sampling}

The data of this research has been collected from Comilla University, Britannia University, and National University. Students of undergraduate level are selected as participants. One hundred and twenty students took part whereas 80 students were female and 40 were male and rests were teachers. The data has been collected through students' and teachers' questionnaire

\subsection{Research Instruments}

Questionnaire method has been used for the students and the teachers as the instrument for collecting data.

\subsection{Survey}

To conduct the survey the researcher had to meet the respondents personally or through social media. In this research, teachers and students survey through questionnaire has been used. Among them, questionnaire method is so beneficial that makes the result quantifiable. Responds took short period of time to fill up questionnaire form. Researcher can easily analyze the answers and sum up the conclusion.

Here, the Likert scale has been used for collecting data from the teachers and students by the researcher. They are:

\begin{tabular}{|l|l|l|l|l|l|l|}
\hline Categories & Strongly agree & Agree & Neutral & Disagree & Strongly Disagree & your opinion, if any \\
\hline No. & 1 & 2 & 3 & 4 & 5 & 6 \\
\hline
\end{tabular}

\section{Data Analysis and Discussion}

4.1 Analysis of the Students' Questionnaire

One hundred twenty students have selected from different non-English major classes who are undergraduates from Comilla University, Britannia University, and National University to collect data. Thirty-six questionnaires have been served to the students by the researcher for collecting correct data.

Table-1: Students' Questionnaire Analysis

\begin{tabular}{|l|l|c|c|c|c|c|}
\hline \multirow{2}{*}{$\begin{array}{l}\text { SL } \\
\text { NO. }\end{array}$} & \multicolumn{1}{|c|}{ Questions } & $\begin{array}{c}\text { Strongly } \\
\text { agree }\end{array}$ & Agree & Neutral & Disagree & $\begin{array}{c}\text { Strongly } \\
\text { disagree }\end{array}$ \\
\hline 1. & $\begin{array}{l}\text { Do you feel that your basic knowledge of } \\
\text { grammar and sentence structure is not enough } \\
\text { to communicate your ideas in English? }\end{array}$ & $21.5 \%$ & $\mathbf{4 5 . 6 \%}$ & $12.7 \%$ & $13.9 \%$ & $6.3 \%$ \\
\hline 2. & $\begin{array}{l}\text { Do you have problems with spelling English } \\
\text { words? }\end{array}$ & $32.7 \%$ & $\mathbf{3 2 . 9 \%}$ & $16.7 \%$ & $15.2 \%$ & $2.5 \%$ \\
\hline 3. & $\begin{array}{l}\text { Have you problems using punctuation marks } \\
\text { properly? }\end{array}$ & $\mathbf{3 6 . 7 \%}$ & $22.8 \%$ & $26.6 \%$ & $3.8 \%$ & $10.1 \%$ \\
\hline 4. & $\begin{array}{l}\text { Do you have problems with vocabulary? Can } \\
\text { you think of appropriate English words to use } \\
\text { in my writing? }\end{array}$ & $17.7 \%$ & $\mathbf{6 0 . 8 \%}$ & $12.7 \%$ & $8.9 \%$ & $0 \%$ \\
\hline
\end{tabular}




\begin{tabular}{|c|c|c|c|c|c|c|}
\hline \multirow{2}{*}{$\begin{array}{l}\text { SL } \\
\text { NO. }\end{array}$} & \multirow[b]{2}{*}{ Questions } & \multicolumn{5}{|c|}{ Results } \\
\hline & & $\begin{array}{l}\text { Strongly } \\
\text { agree }\end{array}$ & Agree & Neutral & Disagree & $\begin{array}{l}\text { Strongly } \\
\text { disagree }\end{array}$ \\
\hline 5. & $\begin{array}{l}\text { Do you have problems with using transition } \\
\text { words between sentences to make your writing } \\
\text { smooth? }\end{array}$ & $11.4 \%$ & $63.3 \%$ & $13.9 \%$ & $7.6 \%$ & $3.8 \%$ \\
\hline 6. & $\begin{array}{l}\text { I don't know how to plan my writing. I don't } \\
\text { know how to start writing and develop the } \\
\text { content. }\end{array}$ & $12.7 \%$ & $45.6 \%$ & $20.3 \%$ & $15.2 \%$ & $6.3 \%$ \\
\hline 7. & $\begin{array}{l}\text { I have no knowledge about the format and } \\
\text { conventions of good writing genres (e.g. } \\
\text { paragraphs, essays). I don't know what a good } \\
\text { paragraph or essay should look like. }\end{array}$ & $26.6 \%$ & $39.2 \%$ & $21.5 \%$ & $7.6 \%$ & $5.1 \%$ \\
\hline 8. & $\begin{array}{l}\text { Do You practice creative writing outside the } \\
\text { classroom? }\end{array}$ & $3.8 \%$ & $11.4 \%$ & $20.3 \%$ & $29.1 \%$ & $35.4 \%$ \\
\hline 9. & $\begin{array}{l}\text { Do you familiar with different types of writing } \\
\text { strategies through which you will able to write } \\
\text { excellent English? }\end{array}$ & $6.3 \%$ & $7.6 \%$ & $22.8 \%$ & $21.5 \%$ & $41.8 \%$ \\
\hline 10. & $\begin{array}{l}\text { Do you have sufficient command over the } \\
\text { subject-verb agreement for writing in English? }\end{array}$ & $6.3 \%$ & $17.7 \%$ & $27.8 \%$ & $41.8 \%$ & $6.3 \%$ \\
\hline 11. & $\begin{array}{l}\text { Are you more concerned about grammar than } \\
\text { an organization of ideas? }\end{array}$ & $13.9 \%$ & $44.3 \%$ & $17.7 \%$ & $20.3 \%$ & $3.8 \%$ \\
\hline 12. & Can you translate lectures in class? & $6.3 \%$ & $15.2 \%$ & $24.1 \%$ & $2.5 \%$ & $51.9 \%$ \\
\hline 13. & $\begin{array}{l}\text { Do you maintain grammatical rules while } \\
\text { noting down lectures in class? }\end{array}$ & $6.3 \%$ & $7.6 \%$ & $13.9 \%$ & $26.6 \%$ & $45.6 \%$ \\
\hline 14. & $\begin{array}{l}\text { Do You feel motivated in non-major English } \\
\text { classes? }\end{array}$ & $15 \%$ & $25 \%$ & $5 \%$ & $25 \%$ & $30 \%$ \\
\hline 15. & $\begin{array}{l}\text { Do You help one another while facing } \\
\text { problems in writing English? }\end{array}$ & $15 \%$ & $20 \%$ & $5 \%$ & $45 \%$ & $15 \%$ \\
\hline 16. & $\begin{array}{l}\text { Are you familiar with all the grammatical rules } \\
\text { that are necessary to write English? }\end{array}$ & $10 \%$ & $15 \%$ & $20 \%$ & $35 \%$ & $20 \%$ \\
\hline 17. & $\begin{array}{l}\text { Do You try to enrich your vocabulary every } \\
\text { day? }\end{array}$ & $15 \%$ & $20 \%$ & $10 \%$ & $35 \%$ & $20 \%$ \\
\hline 18. & $\begin{array}{l}\text { Do You need more Courses in English to } \\
\text { develop writing skills? }\end{array}$ & $29.1 \%$ & $60.8 \%$ & $8.9 \%$ & $1.3 \%$ & $0 \%$ \\
\hline 19. & $\begin{array}{l}\text { Do You give less time on English courses than } \\
\text { major courses? }\end{array}$ & $30 \%$ & $45 \%$ & $2 \%$ & $10 \%$ & $12 \%$ \\
\hline 20. & $\begin{array}{l}\text { Does Your teacher encourage practicing } \\
\text { writing skills in the classroom? }\end{array}$ & $10 \%$ & $5 \%$ & $10 \%$ & $35 \%$ & $40 \%$ \\
\hline 21. & Can you easily write on any relevant topic? & $5 \%$ & $10 \%$ & $5 \%$ & $25 \%$ & $55 \%$ \\
\hline 22. & $\begin{array}{l}\text { Do You use brainstorming before writing any } \\
\text { topic? }\end{array}$ & $19 \%$ & $3.8 \%$ & $16.5 \%$ & $5.1 \%$ & $55.7 \%$ \\
\hline 23. & $\begin{array}{l}\text { Do You feel confident in your ability to express } \\
\text { your ideas in writing? }\end{array}$ & $5.1 \%$ & $2.5 \%$ & $27.8 \%$ & $25.3 \%$ & $39.2 \%$ \\
\hline 24. & $\begin{array}{l}\text { Do you like the teaching strategies in the } \\
\text { English class? }\end{array}$ & $5 \%$ & $10 \%$ & $5 \%$ & $30 \%$ & $50 \%$ \\
\hline 25 & $\begin{array}{l}\text { Is your Class time allocated for learning not } \\
\text { enough? }\end{array}$ & $11.4 \%$ & $48.1 \%$ & $21.5 \%$ & $17.7 \%$ & $1.3 \%$ \\
\hline 26. & $\begin{array}{l}\text { Do you want to receive corrective feedback } \\
\text { (e.g., provide a hint for you to self-correct, tell } \\
\text { you that you made an error, or correct your } \\
\text { error.) when you make mistakes? }\end{array}$ & $10 \%$ & $15 \%$ & $15 \%$ & $35 \%$ & $25 \%$ \\
\hline 27. & $\begin{array}{l}\text { No chance for giving feedback on writing in } \\
\text { the classroom }\end{array}$ & $40 \%$ & $30 \%$ & $5 \%$ & $10 \%$ & $15 \%$ \\
\hline 28. & $\begin{array}{l}\text { Do you pay more attention to language than } \\
\text { content? }\end{array}$ & $45 \%$ & $30 \%$ & $5 \%$ & $15 \%$ & $5 \%$ \\
\hline
\end{tabular}




\begin{tabular}{|c|c|c|c|c|c|c|}
\hline \multirow{2}{*}{$\begin{array}{l}\text { SL } \\
\text { NO. }\end{array}$} & \multirow[b]{2}{*}{ Questions } & \multicolumn{5}{|c|}{ Results } \\
\hline & & $\begin{array}{l}\text { Strongly } \\
\text { agree }\end{array}$ & Agree & Neutral & Disagree & $\begin{array}{l}\text { Strongly } \\
\text { disagree }\end{array}$ \\
\hline 29. & $\begin{array}{l}\text { In written assignments, do you usually follow } \\
\text { the steps of writing? }\end{array}$ & $10.1 \%$ & $1.3 \%$ & $17.7 \%$ & $12.7 \%$ & $58.2 \%$ \\
\hline 30. & $\begin{array}{l}\text { Do You use formal English when using the } \\
\text { Internet or SMS? }\end{array}$ & $5 \%$ & $5 \%$ & $15 \%$ & $40 \%$ & $35 \%$ \\
\hline 31. & $\begin{array}{l}\text { Do internet networking and SMS chatting } \\
\text { affect your English writing? }\end{array}$ & $13.9 \%$ & $60.8 \%$ & $16.5 \%$ & $6.3 \%$ & $2.5 \%$ \\
\hline 32. & $\begin{array}{l}\text { Do you think that lack of vocabulary is a } \\
\text { reason for poor essay writing? }\end{array}$ & $43 \%$ & $49.4 \%$ & $1.3 \%$ & $3.8 \%$ & $2.5 \%$ \\
\hline 33. & $\begin{array}{l}\text { Do your teachers encourage you to write } \\
\text { English outside the classroom? }\end{array}$ & $10 \%$ & $5 \%$ & $10 \%$ & $30 \%$ & $45 \%$ \\
\hline 34. & $\begin{array}{l}\text { Do you usually make a first draft beforehand in } \\
\text { your final draft? }\end{array}$ & $8 \%$ & $5 \%$ & $11 \%$ & $35 \%$ & $41 \%$ \\
\hline 35. & $\begin{array}{l}\text { Do You feel better when your teacher corrects } \\
\text { errors/mistakes in the classroom }\end{array}$ & $20 \%$ & $15 \%$ & $5 \%$ & $45 \%$ & $15 \%$ \\
\hline 36. & $\begin{array}{l}\text { Do you feel angry or embarrassed, When your } \\
\text { teacher gives you negative feedback? }\end{array}$ & $30 \%$ & $40 \%$ & $10 \%$ & $15 \%$ & $5 \%$ \\
\hline
\end{tabular}

\subsection{Teacher's Questionnaire analysis}

The researcher used a close-ended questionnaire to find out data from teachers. The questionnaire was distributed to teachers of three universities (Comilla, Britannia, and National University). The teachers' questionnaires included 25 questions with fixed alternatives.

Table-2: Teachers' Questionnaire Analysis

\begin{tabular}{|l|c|c|c|c|c|}
\hline \multirow{2}{*}{ Questions } & \multicolumn{4}{|c|}{ Results } \\
\cline { 2 - 6 } & $\begin{array}{c}\text { Strongly } \\
\text { Agree }\end{array}$ & Agree & Neutral & Disagree & $\begin{array}{c}\text { Strongly } \\
\text { Disagree }\end{array}$ \\
\hline $\begin{array}{l}1 . \quad \text { There is no need for teachers to provide } \\
\text { feedback on students' errors in writing. }\end{array}$ & $2 \%$ & $5 \%$ & $3 \%$ & $30 \%$ & $\mathbf{6 0} \%$ \\
\hline $\begin{array}{l}2 . \quad \text { Teachers should provide feedback on } \\
\text { student errors selectively. }\end{array}$ & $20 \%$ & $\mathbf{7 0 \%}$ & $3 \%$ & $6 \%$ & $1 \%$ \\
\hline $\begin{array}{l}3 . \quad \text { It is the teacher's job to locate errors and } \\
\text { provide corrections for students. }\end{array}$ & $10 \%$ & $\mathbf{4 5 \%}$ & $5 \%$ & $30 \%$ & $10 \%$ \\
\hline $\begin{array}{l}4 . \quad \text { Teachers should vary their error } \\
\text { feedback techniques according to the type of } \\
\text { error. }\end{array}$ & $15 \%$ & $\mathbf{7 0 \%}$ & $5 \%$ & $3 \%$ & $7 \%$ \\
\hline $\begin{array}{l}5 . \quad \text { Coding errors with the help of a marking } \\
\text { code is a useful means of helping students correct } \\
\text { errors for themselves. }\end{array}$ & $15 \%$ & $\mathbf{7 0 \%}$ & $2 \%$ & $8 \%$ & $5 \%$ \\
\hline $\begin{array}{l}6 . \quad \text { Marking codes should be easy for } \\
\text { students to follow and understand. }\end{array}$ & $\mathbf{5 0 \%}$ & $40 \%$ & $3 \%$ & $5 \%$ & $3 \%$ \\
\hline $\begin{array}{l}7 . \quad \text { Students should learn to locate their own } \\
\text { errors. }\end{array}$ & $30 \%$ & $\mathbf{6 0 \%}$ & $5 \%$ & $3 \%$ & $2 \%$ \\
\hline $\begin{array}{l}8 . \quad \text { Students should learn to locate and } \\
\text { correct their own errors. }\end{array}$ & $30 \%$ & $\mathbf{6 0 \%}$ & $7 \%$ & $2 \%$ & $3 \%$ \\
\hline $\begin{array}{l}9 . \quad \text { Students should learn to analyze their } \\
\text { own errors. }\end{array}$ & $30 \%$ & $\mathbf{5 5 \%}$ & $5 \%$ & $6 \%$ & $4 \%$ \\
\hline $\begin{array}{l}10 . \quad \text { Do you think students write accurately in } \\
\text { their exam papers? }\end{array}$ & $5 \%$ & $10 \%$ & $10 \%$ & $\mathbf{4 5 \%}$ & $30 \%$ \\
\hline $\begin{array}{l}11 . \quad \text { Do you agree that students make } \\
\text { grammatical errors while writing? }\end{array}$ & $\mathbf{6 0 \%}$ & $20 \%$ & $5 \%$ & $10 \%$ & $5 \%$ \\
\hline $\begin{array}{l}12 . \quad \text { Do you think students make spelling } \\
\text { errors while writing? }\end{array}$ & $30 \%$ & $\mathbf{4 0 \%}$ & $5 \%$ & $15 \%$ & $10 \%$ \\
\hline $\begin{array}{l}13 . \quad \text { Students have a lack of vocabulary } \\
\text { knowledge }\end{array}$ & $\mathbf{5 0 \%}$ & $30 \%$ & $10 \%$ & $5 \%$ & $5 \%$ \\
\hline
\end{tabular}




\begin{tabular}{|c|c|c|c|c|c|}
\hline \multirow[b]{2}{*}{ Questions } & \multicolumn{5}{|c|}{ Results } \\
\hline & $\begin{array}{l}\text { Strongly } \\
\text { Agree }\end{array}$ & Agree & Neutral & Disagree & $\begin{array}{l}\text { Strongly } \\
\text { Disagree }\end{array}$ \\
\hline $\begin{array}{l}14 . \quad \text { Students don't focus on their writing } \\
\text { content }\end{array}$ & $40 \%$ & $30 \%$ & $5 \%$ & $15 \%$ & $10 \%$ \\
\hline $\begin{array}{l}\text { 15. The English course in non-English } \\
\text { department is enough }\end{array}$ & $10 \%$ & $15 \%$ & $10 \%$ & $45 \%$ & $20 \%$ \\
\hline $\begin{array}{l}16 . \quad \text { Students spend less time on their English } \\
\text { courses. }\end{array}$ & $40 \%$ & $30 \%$ & $5 \%$ & $15 \%$ & $10 \%$ \\
\hline $\begin{array}{l}17 . \quad \text { Some more courses are needed in non- } \\
\text { English Major department for good writing skills. }\end{array}$ & $40 \%$ & $35 \%$ & $5 \%$ & $15 \%$ & $5 \%$ \\
\hline $\begin{array}{l}\text { 18. Students need to practice outside the } \\
\text { classroom }\end{array}$ & $45 \%$ & $30 \%$ & $10 \%$ & $10 \%$ & $5 \%$ \\
\hline $\begin{array}{l}\text { 19. A teacher can motivate his/her students } \\
\text { in developing writing skill }\end{array}$ & $50 \%$ & $30 \%$ & $2 \%$ & $8 \%$ & $10 \%$ \\
\hline $\begin{array}{l}20 . \quad \text { Use GTM method to teach grammar in } \\
\text { the classroom }\end{array}$ & $10 \%$ & $10 \%$ & $20 \%$ & $35 \%$ & $25 \%$ \\
\hline $\begin{array}{l}\text { 21. Teachers from non-English Major } \\
\text { Department should be trained on English } \\
\text { grammatical rules }\end{array}$ & $50 \%$ & $20 \%$ & $5 \%$ & $15 \%$ & $10 \%$ \\
\hline $\begin{array}{l}22 . \quad \text { You identify students' errors while } \\
\text { checking exam scripts. }\end{array}$ & $35 \%$ & $25 \%$ & $10 \%$ & $20 \%$ & $10 \%$ \\
\hline $\begin{array}{l}23 . \quad \text { Non-English major course teachers also } \\
\text { should have good knowledge in English }\end{array}$ & $35 \%$ & $25 \%$ & $10 \%$ & $25 \%$ & $5 \%$ \\
\hline $\begin{array}{l}24 . \quad \text { Change in the syllabus design can } \\
\text { develop the writing skill of non-English major } \\
\text { department's students. }\end{array}$ & $50 \%$ & $20 \%$ & $5 \%$ & $15 \%$ & $10 \%$ \\
\hline $\begin{array}{l}25 . \quad \text { Marking an answer should be based on } \\
\text { good writing skill by maintaining all grammatical } \\
\text { rules. }\end{array}$ & $40 \%$ & $30 \%$ & $2 \%$ & $20 \%$ & $8 \%$ \\
\hline
\end{tabular}

\subsection{Discussion in Terms of Students' Perspective}

After the investigation, the researcher found the answer to the central research question 1, after analyzing the problem no 2,3,4,5,7,10,21,28,29,31,32 (see Table1). Among the students, most of them strongly agreed that they view writing as a challenging task. Most of the students strongly agreed that they face writing problems using spelling, proper punctuation, transition words, and appropriate vocabulary. If grammar is the skeleton of language, then vocabulary is the flesh. Without having adequate command in grammar and vocabulary, students cannot achieve good marks in their exams. Most of the students agreed that they don't have sufficient control over the subject-verb agreement, and they know very few about the format of good writing genres. Errors on Subject and Verb agreement vary. The first type of errors is omission. It refers to the error characterized by the absence of an item that must appear in a well-formed utterance, for example, the missing of verb inflections ( $\mathrm{s}$, es, or ies) and verb auxiliaries ( is, am, and are). The learners tend to omit grammatical morphemes much more frequently than content words such as in He speak English well (Fauziati, 2009. P. 145). The second type is addition. It refers to errors that are characterized by the presence of an item that should otherwise not present in a well-formed utterance including double marking, regulation, and simple addition. E.g. I will learns English. The other one is misformation errors consisting of regulation, archi-forms, and alternating forms, for example the use of he for she, him for he, and etc. The last one is misordering errors. This type of error is characterized by the incorrect placement of a morpheme in an utterance. For example, I don't know what is it. (Fauziati, 2009. P. 147). To score good marks, a student has to muster knowledge about the format as well as conventions of good essays and paragraphs. But they don't have sufficient knowledge about this, and as a result, they fail to get good marks in English writing. For Non-English major undergraduate students, English is nothing but a language only. So they give more focus on language accuracy than the organization of ideas and content. In the practice of writing correct grammar, they failed to convey their ideas to the readers. Free handwriting is an on-going process to develop writing skills. But the non-English major undergraduate students cannot write on any relevant topic easily because they have minimal vocabulary knowledge. Most of the students also strongly agreed that, while chatting through internet or mobile messaging, they use short informal code words, and sometimes they use those colloquial words in exam papers. The above discussing problems are the main reasons for getting abysmal marks in English courses in comparison to other courses. 
The researcher found the answer to the central research question no 2, after analyzing question no 1,6,12,14,19,20,23,24,25,33 ( see Table 1). Motivation in learning the second language is significant. Lack of motivation can create boredom in their interest to learn English effectively. Most of the students strongly agreed that their basic knowledge of grammar and structure are not enough to communicate their ideas in English. As a result, they do not feel confident in their ability to express ideas in writing. These create frustration in them, and they feel demotivated in their English class. The students are asked why they don't feel motivated in class, where most of the students strongly agreed that they do not like the teaching strategies in the English class. Also, they strongly agreed that class time is not enough to learn a language that is completely different from their mother language and sentence structure. Within the allocated 50 minutes, the teacher calls attendance, manages the class environment and then starts delivering lectures. Within this short time, the teacher can't ensure error correction and error feedback in the classroom, mentioning students' writing problems individually. Whereas delivering lectures within a short time is beyond imagination, the teacher does not encourage students to practice writing in the classroom. Students feel unenthusiastic to give more time on English courses than major courses. As they don't enjoy the teaching strategies, they feel demotivated while learning the target language. Teachers do not encourage them to write effectively outside the classroom, so they do not feel motivated to learn English writing. Most of the students do not find any difference between their college standard English and university standard English, especially; they do not find any improvement in their writing. Therefore they become demotivated while writing English. As most of the students cannot cope with the Bangla medium to English version changes, teachers should be the pioneer to encourage them. They will try to make students understand that they should practice writing outside the classroom so that they become motivated to learn English writing skill. The central reason that causes Non-English Major undergraduate students to become demotivated while learning the target language is an imbalance between planning and developing the content. More than 57\% students agreed that they do not know how to plan their writing. As they have insufficient knowledge of writing strategies, grammatical correctness, and organization of ideas, they feel hesitant to respond in the classroom and also feel boring, and these lead to poor motivation to learn English effectively. According to Zamel (1997), the writing class should take into account the learners' purposes for writing. Writing tasks can be developed rapidly when students' concerns and interests are acknowledged when they are given numerous opportunities to write and when they are encouraged to become participants. Davies (1998:25) thinks that learners will be encouraged to write if writing tasks motivate them and keep them interested.

The researcher found the answer to the central research question no 3, after analyzing issue no 35 and 36 (see Table 1). The most common error that students make is in areas of grammar, punctuation, and spelling. Punctuation is important because it tells readers where they need to stop, to pause, or to notice the emphasis. The Spelling error is a standard error that undergraduate students commit while writing an essay or paragraph. When developing an academic essay, learners need to be concerned about the choice of words while constructing a sentence. It is the most frustrating experience for the learners when they cannot find the words they need to express their idea. Students commit different types of errors in their writing. At certain levels, making an error can be taken positively as a sign of students' development, but students' errors are intolerable at the tertiary level. After12 years of studying English, teachers expect learners to be competent in the language. Identifying common errors in students' writing can help teachers work more on the target areas that students face difficulties. Students' error in writing at the tertiary level is now a crucial issue in Bangladesh. Non-English major undergraduate students take error analysis as a matter of anger and embarrassment. Most of them agreed that they do not feel better when the teacher corrects their error/mistakes. They also strongly agreed that if the teacher gives them negative feedback, they feel angry and embarrassed. No-one likes to be told that they are wrong, so sensitivity and care are required when dealing with errors and mistakes from learners. Errors are seen as a systematic deviation made by learners who have not mastered the rules of L2. A learner cannot self-correct his/her errors because they are a reflective product of his/her current L2 development stage. Whereas, mistakes are defined as a random confirmation slip caused by tiredness, excitement, or other sources, and the learner can readily self-correct his/her mistakes. Error Analysis is one of the most influential theories of second language acquisition. So, students should be aware of the importance of error correction in learning English effectively.

The researcher found the answer to the central research question no 4, after analyzing problem no 26 and 27 (see Table 1). Zamel (1985: 79) states that teacher's feedback can be useful if teachers respond to students writing as genuine and interested readers rather than as judges and evaluators. Similarly, Byrne (1988:29) thinks that if we are to be true readers rather than judges, we should perhaps not look at what the learners have failed to achieve but rather at what they succeeded in doing. This might help students, writers, to appreciate receiving comments and use them in their revisions. The researcher asked the students whether they want to receive corrective feedback or not, and then most of the students strongly agreed with three types of feedback, namely: hint for self-correction, identify your error without a hint and identify as well as correct their error by the teacher. Using the red pen is useful since it highlights the places of mistakes and makes them appear to the learner. The researcher thinks that using the red pen in error correction gives the students the chance to realize that something went wrong and needs 
to be dealt with carefully. The researcher also sees that leaving some errors uncorrected for students will encourage them to work on errors by themselves, which creates a suitable environment for learning. Students gave attention to get the errors corrected by the teacher. Students thought that correcting errors by teachers is trustworthy and supportive.

The researcher found the answer to the central research question no 5, after analyzing question no $8,9,11,13,15,16,17,18,22,30$ and 39 (see Table 1). Academic writing entails conscious effort and much practice in organization, language use, and writing procedure. Many factors are affecting non-English major undergraduate academic writing performance, like content, vocabulary, composing, developing, and analyzing ideas. Producing an organized, neat, and error-free piece of writing has always been the lifelong dream and the ambition of all Bangladeshi Tertiary Level students. The first and foremost reason for their writing English weakness is that they are not familiar with all the grammatical rules necessary to write good English. So, the researcher finds it mandatory as a remedy to overcome writing problems. If the students learn all the grammatical rules, they will not face any problems in writing. Most of the students also strongly agreed that they do not attempt to enrich their vocabulary. This poor vocabulary pushes them into danger while trying to convey their ideas. They do not find any right word to imply in their writing. So, the students should try to learn at least 20 vocabularies every day, and this will improve their writing. The Non-English Major undergraduate students look at English courses as a language course only, and for that misunderstanding, they try to give the best effort to correct grammatical problems. By doing so, they are giving less importance in the organization of ideas; As a result, they bring impoverished marks in their wring skill. But students should be more concerned about organization ideas, by communicating with readers about their writing. Unfortunately, most of the students strongly agreed that they have no idea about different writing strategies and never use brainstorming and first draft beforehand in final draft. So, the researcher finds a solution to these problems. To overcome their writing problems, students should know all the writing strategies to write good English. The non-English major students have to know the writing strategies by which they can organize their ideas. Hedge (1988) and White and Arndt (1991) mentioned four stages of process approach like prewriting, composing/drafting, revising, and editing. In the prewriting stage, learners will think about the topic based on something which is given to them. In the composing/ drafting stage, learners will organize their thoughts to make a plan for describing their topic. Lastly, they will revise their first draft and will modify or edit it; they need it (as cited in Badger \& White, 2000, p. 154). Brainstorming should be practiced while writing. To become an excellent writer, they have to practice creative writing outside the classroom. Their creative writing will help them to feel motivated in English Class. Also, the majority of the students strongly agreed that only one course on English is not enough for them as the tertiary level's proficiency is completely different from the secondary level's English standards. So, it can be a solution to their problems. If there will be two or more English courses, they will be able to learn English writing effectively and write error-free English. Outside the classroom, they should be attached to their English learning, and for this, they should maintain formal English with correct spelling as well as grammar in case of noting down lectures in class or using Internet or SMS chatting. There is a proverb that practice makes a man perfect. And this perfection comes forth by repetitive practice inside and outside the classroom.

\subsection{Discussion in Terms of Teachers' Perspective}

The researcher found that almost all the teachers strongly agreed on the central research question no 1(analyzing questions 10,11, 12, 13, 14; see Table 2) that students cannot make a good result. Because they make grammatical and spelling errors, they have lack of vocabulary knowledge, and they cannot organize their ideas.

Most of the teachers believe that students do not pay full attention to their writing skill. The researcher found that most of the teachers think that the students feel bored giving full attention because they do not know all the grammatical rules that are needed for developing themselves. Most of the teachers also strongly agreed that the English course is not enough in non-English department. Within short time duration, teachers can't cover all the four skills adequately. As the students have to cover all the four skills in their English syllabus, they feel demotivated in the English class. Another reason behind their lack of motivation is that spending much time on non-major course is considered a waste of time. They focus more on their major courses, and thus they feel bored in English class. It is focused on the central research question no 2 analyzing the teachers' questionnaire $(15,16)$ (see Table 2).

After analyzing the teachers' questionnaire (1,7,8,9,20 and 22) (see Table 2) related to central research question no 3 , it is found that most of the teachers think that error analysis is time-consuming in non-English major undergraduate students' English class. Around $60 \%$ of the participants agreed that they identify students' errors while checking exam papers. But, few teachers think that teachers provide feedback on students' errors in writing. On the other hand, most of the teachers believe that it is the students' not the teachers' job to identify the error and correct this. Practicing error analysis creates a mix-reaction in Bangladesh. Some agreed, and some disagreed with this error analysis practice. In the Tertiary level, the students are enormous in number, so the teacher can't practice error correction for all students in the classroom. The error analysis shows that about 90 percent of teachers believe 
that students should learn to locate their errors and correct their errors. Teachers' perception is that, students have to be self-dependent in finding, identifying the types of errors and correcting their error.

The researcher found the answer to the central research question no 4, after analyzing question no 2,3,4,5 and 6 (see Table 2). They suggest some strategies of error feedback that should be needed to encourage students to make a good result in the examination and be proficient in writing skills. Error analysis is the first stage of checking the errors/mistakes. But it is necessary to let students know at which point they do mistake/error. Using useful strategies to provide error feedback can motivate a student to learn English effectively and accurately. The feedback analysis shows that about 55per cent of the feedback is direct, i.e., teachers indicate and correct errors for students. Although teachers think students should learn to locate and correct errors, their written feedback practice does not often allow this to happen. About 90 percent shows that teachers should provide feedback on students' errors selectively. Selective error feedback can save time, and students can focus on specific areas, marking all errors cannot help students improve grammatical accuracy. Students are not happy when they get back their compositions full of red marks etc. The vast majority $(85 \%)$ of teachers used a marking code in marking student writing. Although $90 \%$ of teachers think that teachers should provide feedback on errors selectively, in reality, only a minority are practicing it. However, when asked if students should learn to locate and correct errors, $90 \%$ of them believe that students should learn to trace their own errors and $90 \%$ of them think that students should also learn to correct their errors. Teachers, therefore, seem to contradict themselves. Although they are aware of the importance of asking students to take on the responsibility of error location and correction, in reality, teachers may be driven by the daily and pressing demands of students, parents, panel chairs, etc. to shoulder the responsibility of error location and correction. Empowering students to locate and correct errors may only reside at the back of the teachers' minds. Another statement that shows a gap between teachers' beliefs and practice is that $85 \%$ of the teachers think that they should vary their error feedback techniques. Still in reality, the methods they use tend to be mainly restricted to 'indicating and correcting errors' and 'indicating, categorizing and not correcting errors'. The questionnaire results show that many teachers are self-contradictory when they express their views of the responsibility of error location and correction - whether it is the teachers' or the students' job. In answer to the central research question no 5, most of the teachers think that syllabus design changes can have a good effect on writing skills. For example, some basic grammatical courses can be added to the syllabus to have pure grammatical knowledge. From the teachers' questionnaire $(17,18,19,21,23,24,25)$ (see- Table 2), it is clear that a teacher should judge a student by his/her writing skill. Most of the teachers pointed out that every student should practice writing outside the classroom. The Majority of them agreed that some more courses are needed in non-English major department for good writing English. After doing one class of English, if students are left untouched with English writing, surely they can forget the grammatical rules and writing strategies. So, to keep this practice continuing, the teachers from non-English major departments should be trained on English. They can easily motivate their students to improve their English writing when they possess good knowledge in English.

\section{Conclusion and Recommendations}

In Bangladesh, writing skill is always avoided all over the entire academic life of a student. Academic writing course is not sufficient in our country, which hampers the improvement of academic skill in English. The study will aid the learners to recognize their writing problems which will eventually contribute to improve their writing skill. Equally, the teachers of language course will be vastly benefited by the awareness of the learners' writing problems in details and the study will be a helpful ways to facilitate the learners further improve the writing skill. Based on the data analysis findings, some recommendations are given below through which the writing problems of non-English major undergraduate can be solved fruitfully:

1) The findings suggest that the number of English courses that are offered for non-departments are not efficient. It is strongly suggested that the Academic English writing courses should be increased for them to strengthen writing skill.

2) Many undergraduate students are still weak in Bengali writing, let alone in writing English because they are not taught how to write academically even in their mother language. If these students are taught the basics and strategies of writing in general, they will learn to write in the exam as well as acquire the ability to produce analytical writing on any topic. Mastering L1 is very important to acquire proficiency in L2.

3) To enhance vocabulary, the students should follow Oxford Advanced Learner's Dictionary to find unknown and difficult words. Also, they should uphold a diary to note down the practice of these words.

4) When students write in English, teachers should frequently remind their students that they must think in English rather than in Bangla which is their LI. It could have reduced their tendency of brining any feature of the mother tongue in the target language.

5) In giving feedback teacher should explain why certain constructions are faulty.

6) Teachers should encourage their students to write by providing helpful criticisms. They should make constructive criticisms of their students' work.

7) Teachers should be aware of how they correct students' errors and need to avoid using correction strategies 
that might humiliate students in front of other students in class.

8) Teachers should be sensitive when correcting their students' errors and should remind them that it is natural for learners to make errors in the process of acquiring the target language.

9) Students must be familiar with free handwriting and they have to practice it by writing on open topics in English.

10) Different types of writing strategies should be learnt and taught in the classroom.

11) At the time of noting down the lecture, students should follow all the grammatical rules in English.

12) The Students should use brainstorming techniques before writing anything in English. Brainstorming will help them to plan, order and organize ideas in any specific topic.

13) The teacher should avoid teaching in GTM method. Leaving authority, the teacher should behave with students as a mentor through CLT method.

14) In case of error feedback, the teacher should underline the error so that students can correct their error themselves. This will boost their confidence in L2 language.

15) Although students like to get corrective feedback from the teacher, the teacher should not correct all the errors. If they ask students to categorize the error type and re-correct themselves, it will motivate them to selfcorrection.

16) Curriculum design should be revised for non-departments students. The questions set for the exams should be creative, not repetitive. Improving writing problems should be treated as a long-term job.

17) The English teachers need to spend a great deal of time checking, marking and giving feedback to their students.

18) The students can be assigned to read each other's writing script and provide feedback to each other. Based on that feedback the students can rewrite and finalize their writing.

19) Teachers should include materials for all levels of students. For the keen students teachers can arrange some difficult and extended exercise.

20) Teachers should not express their prejudice to stronger students and look down the weaker students. Each and every student should be treated equally.

21) To make the teaching- learning process enjoyable, the teachers of English should use various teaching aids.

\section{References}

1. Ahmad, N., Khan, F.N. and Munir, N. (2013). 'Factors affecting the learning of English at secondary school level in Khyber Pakhtunkhwa, Pakistan'. International journal of English language and Literature studies, 2(2), pp.95-101.

2. Ahmed, S. (1999). 'The problem of teaching English grammar to Bengali-speaking students'. Collected Papers, pp.167-172.

3. Badger, R. and White, G. (2000). 'A process genre approach to teaching writing'. ELT journal, 54(2), pp.153160.

4. Bilal, H.A., Tariq, A.R., Din, N., Latif, H. and Anjum, M.N.( 2013). 'Investigating the problems faced by the teachers in developing English writing skills'. Asian Journal of Social Sciences and Humanities, 2(3), pp.238244.

5. Byrne, D. (1988). Teaching Writing Skills. London: Longmann.

6. Cohen, A. and Cavalcanti, M. (1990). 'Feedback on compositions: Teacher and student verbal reports'. In. B. Kroll (Ed.), Second language writing: Research insights for the classroom (pp. 155-177).

7. Dar, M.F. and Khan, I. (2015). 'Writing anxiety among public and private sectors Pakistani undergraduate university students'. Pakistan Journal of Gender Studies, 10(1), pp.121-136.

8. Davis, S. (1988). Keywords in Creative Writing. Utah State University Press :Logan, Utah

9. Fahmida, B. (2010). Bangladeshi tertiary level students' common errors in academic writing (Doctoral dissertation, BRAC University).

10. Ferris, D.R. (1995). 'Student reactions to teacher response in multiple-draft composition classrooms'. TESOL quarterly, 29(1), pp.33-53.

11. Geiser, S. and Studley, W.R. (2002). 'UC and the SAT: Predictive validity and differential impact of the SAT I and SAT II at the University of California'. Educational Assessment, 8(1), pp.1-26.

12. Grabe, W. and Kaplan, R.B. (1996). Theory and Practice of Writing. London and New York.

13. Graham, S. and Perin, D. (2007). Writing next-effective strategies to improve writing of adolescents in middle and high schools. Washington,DC:Alliance for Excellent Education.

14. Haider, G. (2012). 'An insight into difficulties faced by Pakistani student writers: Implications for teaching of writing'. Journal of Educational and Social Research, 2(3), pp.17-27.

15. Heaton, J.B. (1975). Writing English language tests: A practical guide for teachers of English as a second or foreign language. Longman Publishing Group. Hedge, T. (1988). Writing. Oxford: Oxford University Press.

16. Hyland, K. (2019). Second language writing. Cambridge university press. 
17. Jordan, R.R. and Jordan, R.R., 1997. English for academic purposes: A guide and resource book for teachers. Cambridge University Press.

18. Kellogg, R.T. (2001). 'Long-term working memory in text production'. Memory \& cognition, 29(1), pp.4352.

19. Kroll, B., Long, M.H. and Richards, J.C. eds., (1990). Second language writing (Cambridge applied linguistics): Research insights for the classroom. Cambridge University Press.

20. Mahboob, A. (2014). 'Epilogue: Understanding language variation: Implications for eil pedagogy'. The pedagogy of English as an international language: Perspectives from scholars, teachers, and students, pp. $257-265$.

21. Mahboob, A., \& Talaat, M. (2008). English language teachers and Teacher education in Pakistan. TESOL, Alexandria, USA.

22. McCutchen, D. (1984). 'Writing as a linguistic problem'. Educational Psychologist, 19(4), pp.226-238.

23. Musa, F. (2010). 'Teaching writing to post-secondary students: Procedure and technicalities in an EFL classroom'. In First National Conference on English Language Teaching, Al-Quds Open University, Palestine. Retrieved from http://www. qou. edu/english/conferences/firstNationalConference/pdfFiles/farouqMusa. pdf.

24. Mustaque, S. (2014). 'Writing Problems among the Tertiary Level Students in Bangladesh: A Study in Chittagong Region'. Language in India, 14(1).

25. Leki, I. (1991). 'Twenty-five years of contrastive rhetoric: Text analysis and writing pedagogies'. Tesol Quarterly, 25(1), pp.123-143.

26. Nickerson, R.S., Perkins, D.N. and Smith, E.E. (2014). The teaching of thinking. Routledge.

27. Nik, Y.A., Hamzah, A. and Rafidee, H. (2010). 'A comparative study on the factors affecting the writing performance among bachelor students'. International Journal of Educational Research and Technology, 1(1), pp.54-59..

28. Norrish, J. (1983). Language learners and their errors. VCTA.

29. Pincas, A. (1982). Teaching English writing. Macmillan Press.

30. Quintero, L.M. (2008). 'Blogging: A way to foster EFL writing'. Colombian Applied Linguistics Journal, (10), pp.7-49.

31. Raimes, A. (1983). Techniques in teaching writing. Oxford University Press, 200 Madison Ave., New York, NY 10016 (ISBN-0-19-434131-3, \$5.95)..

32. Raimes, A. (2005). Keys for writers. Boston: Houghton Mifflin.

33. Rico, L.J.A. (2014). 'Identifying factors causing difficulties to productive skills among foreign languages learners'. Opening writing doors journal, 11(1), pp.65-86.

34. Silva, T. (1990). 'Second language composition instruction: Developments, issues, and directions in ESL'. Second language writing: Research insights for the classroom, pp.11-23.

35. Tyner, E. (1987). College Writing Basics: A Progressive Approach. Belmont. Wands Worth Publishing Company.

36. White, R.V. (1980). Teaching Writing English. London: George Allen and Unwin.

37. White, R. and Arndt, V. (1991). Process writing. London: Longman.

38. Zamel, V. (1982). 'Writing: The process of discovering meaning'. TESOL quarterly, 16(2), pp.195-209.

39. Zamel, V. (1985). 'Responding to student writing'. Tesol Quarterly, 19(1), pp.79-101.

40. Fauziati, E. (2009). Readings on Applied Linguistics: A Handbook for Language Teacher and Teacher Researcher. Pustaka Utama 